The Geneva Papers on Risk and Insurance, 19 (No. 72, July 1994) 304-333

\title{
Insurance: The Future Has Begun
}

\author{
by Felix Mansilla*
}

\section{Insurance: The future has begun}

Some years ago, a book called "The future has begun" was published in Spain. Its aim was to show that the future begins at any moment of the present, that the shape of the future is already around us, but that we are prevented from seeing it by a lack of perspective. Moreover, we are controlled by the mental categories of the past. The facts are usually in advance of the mentalities that perceive them.

Although I am aware of my limitations, I would like to make an attempt at bringing out the events that are occurring now which are of the greatest significance for the future of the insurance business. I will then go on to attempt to situate insurance and the insurance industry in its economic, social and political context, the factors that affect it and, finally, to point out the features that are most likely to define the future of insurance in Spain, as a fraction of the insurance business in the European Union, in order to continue to provide Spanish society with the increasingly sophisticated services that it is going to start asking insurance companies to provide.

As is only natural and as occurs in this field and in other areas, most predictions fail to become true, either wholly or in part. However, in spite of this, I believe that raising oneself above everyday routine problems and trying to look at the industry over a longer time-scale is an exercise that is worth the effort. We all know that executives - not only in the insurance industry - are sorely tempted to put off important matters and give preference to urgent ones.

\section{Factors affecting the future of insurance business: Economic and political environment}

It is well known that insurance business is dependent on macroeconomic and microeconomic trends, as well as on the sociological, educational and ethical changes taking place in society. Neither can one overlook the fact that insurance legislation and control is heavily dependent on political decisions taken at all levels (EU, national Government and Parliament. Regional Authorities and even Local Authorities). I shall now provide a summary of two major blocks of variables that are subjectively felt to have a greater influence, be it direct or indirect, on the future activity of the insurance business.

* Chairman, UNESPA, Madrid. Paper presented at the 30th Annual Seminar of the International Insurance Society, Madrid, June 19-23, 1994. 
The first block relates to the economic and political environment and includes the following sections :

- Internationalization of national economies

- Increasing interdependence of such economies

- Creation of large economic areas

- The political and economic collapse of socialist countries with planned economies

- Universal acceptance of the idea of market economies

- Structural economic crisis.

The second block aims at identifying the elements of the insurance environment that have the greatest bearing on the future development of insurance companies in Spain and in Europe.

- Crisis in the Social Security systems in Europe

- Liberalization of legislation (incorrectly called deregulation)

- Increased international competition

- New financial products and "bancassurance"

- Generalized technical losses

- The fall in interest rates.

\subsection{The internationalization of the economy and the economic interdependence of nations}

Nobody puts in doubt the fact that the economy is becoming increasingly international, or as it is sometimes called, global. The logical corollary of this trend is that national and regional economies are becoming more and more interdependent.

The problems of the United States affect Europe and vice versa. And, from the point of view of Spain, any problem that appears in any country in the European Union affects the Spanish economy to a greater or lesser extent.

The realization that no country, not even one with a huge domestic market like the United States, can be economically self-sufficient, together with the idea of liberalization of legislation and of the economy, which have been given a boost by the recent GATT agreements on services in Marrakech, has led to a trend towards opening up frontiers to trade felt even more strongly among countries in the European Union - which is most important in the area of insurance.

First of all, it should be pointed out that insurance has, by its very nature, always been international. The spreading of risks geographically is an essential feature for providing compensation for risks.

Insurance of international trade and exports and imports of goods, particularly by sea, has always been international.

Likewise, international reinsurance is the stage that is inevitably reached when insurers pursue the principles of dividing up and spreading risks. For instance, when the Andrew Dorian sank, nearly 50 countries paid a large part of the cost of the accident, only a small part of which was borne by the Italian economy. The sharing of losses among several economies is one of the major stabilising contributions of reinsurance for national economies.

More recently, cover for nuclear-related damages and liabilities, where the potential losses involved in a single accident cannot be taken on by any single country (not even by 
the United States, Russia or Japan), is insured through national pools (groups of insurance and reinsurance underwriters), who spread the risks undertaken by the pool of each one of them among a large number of countries.

Along side these traditional practices that aim at spreading risks internationally, which have always been a facet of insurance, other new factors are appearing, such as the generalized internationalization of the economies and, in particular, the construction of the Single European Market, involving new single systems of licensing and control and the freedom to provide services across frontiers. This has led to a different type of international expansion: large insurance companies are now massively present in other markets. The situation in Spain and other European countries is clear evidence of this trend.

This expansion has been taking place in various different ways. One way has been to set up branches in other countries, taking advantage of the ban on discrimination of any kind between member States of the European Union. Another method used has been to set up subsidiary companies. This has usually been done by acquiring majority holdings in the capital of companies in the country where the insurance company intends to start doing business. In this way, business is carried on through a company of the country concerned. This is a method that can be used by American, Japanese or Swiss companies in order to gain access to the advantages of the European Union (only for Life business).

Another system used in Spain consists of subscribing to large proportions (of up to $50 \%$ ) of the capital of large insurance companies in the country where the insurance company wishes to do business. Finally, another system, which has not yet been used on any large scale, is to operate in a Community country without having any establishment in that country, directly from the country of origin, offering original products, by virtue of the so called free provision of services across frontiers, inside the area of the European Economic Community.

There is no need to say that by establishing a presence, in any of the many forms that are possible, in other markets, insurance companies are able:

a) To follow their industrial and trading customers from their own country in their operations in other markets. This is helped by the possibility provided for under Community Law to insure all the establishments of an industrial business entity in different countries of the European Union, in a single policy taken out in the country where the insured has its head offices, and under identical terms. This favours countries that export capital and technology.

b) To become more competitive, since, for example, a multinational insurance company operating in the 16 countries of the European Union might theoretically make a prospective corporate policyholder sixteen offers with sixteen premiums and sixteen sets of law applying to the insurance contract, whereas an insurer operating only in its own country will only be able to make a single offer, without any alternative.

c) To spread their risks even more widely, which in colloquial language could be expressed by the old saying "Don't put all your eggs in one basket". Internationalization, obviously coupled with good management, should allow for the losses made in one country to be offset by profits made in others, with different economies, rates of inflation, tax systems and currencies.

As can be seen, the internationalization of economies has had a major impact - which can only grow in the future - on the development of insurance and on the structure and 
conditions of insurance products on offer. It is, therefore, not difficult to predict that one of the features of insurance business in the future will be strong competition, as a result of over-supply, which may affect premium levels and, in the long term, solvency margins.

The increasing inter-dependence of national economies is occurring almost everywhere. Not even China which is, together with North Korea, the last redoubt of state planned economics, has managed to escape this trend.

One effect of inter-dependence, which is being felt by industrial companies and, indirectly, by insurance as well, is that the cost of labour in certain Asian countries may be as much as ten times cheaper than labour costs in Europe, the United States or Japan. Something similar is happening, albeit to a lesser extent, in some Eastern European countries.

This phenomenon, sometimes referred to as "social dumping", is reducing investment in Western European countries and even encouraging companies to delocate from these countries. This has two effects. On the one hand, the value added in Europe in large industrial companies has decreased. The other effect is higher unemployment (where this trend is one of the causes, together with other factors).

As insurance is dependent on trends in the economy, the slowing down of industrial growth in Europe has had an adverse effect on insurance business as there has been a drop in new business underwritings.

\subsection{The creation of large regional economic areas}

One logical consequence of the internationalization of economies is the creation of large regional economic areas, each including a number of countries.

The example closest to and directly experienced by Spaniards is twofold. Firstly, the OECD, with its Code of Liberalization which has now become out-dated, was for a time a considerable advance. Secondly, and above all, the EEC, especially after the setting up of the Single Market.

As is known, the idea of a Single Market is that of a Common Market, after all the freedoms provided for in the Treaty of Rome which set up the Common Market have been included in legislation and have appeared as an economic reality. It is also worth noting that the term European Economic Community, EEC, remains valid when referring to economic matters, while the term European Union has come into general use preferably when talking about political aspects.

The freedoms that most affect insurance are: 1) Freedom of establishment; 2) Freedom to provide services; and 3) Freedom of movement of capital.

The freedom to provide services (across frontiers) provides for a level of freedom hitherto unknown (except, to some extent, in the field of reinsurance). Not even in the United States, the champion of free enterprise, does such freedom exist, because an insurance company from one State that wishes to operate in another State must open an establishment in that State.

This freedom has attracted insurance companies from countries outside the European Union, since, for instance, an American insurance company that acquires a majority of the capital of a company in Spain or in any other country in the European Union, may operate throughout the entire European Economic Community, from a single country, under its 
right to freedom to provide services. As EEC Law does not "lift the veil" of the companies' status as legal entities, an insurance company in the EEC shall have this nature and may not be discriminated against, even when all or most of its capital is held by persons or companies from outside the EEC.

As a result, one finds that, in addition to the strong presence of insurance companies from other EEC countries in the Spanish market, one must add those companies from outside the EEC, from countries such as the United States, Japan, Switzerland, Brazil, etc.

Switzerland is a special case, because it has signed an agreement with the EEC for Non-Life Insurance, under which Swiss insurance companies are allowed to have the status of EEC companies. This is not the case, however, for Life Insurance, where Swiss companies are still regarded as non-EEC companies.

There are several regional agreements which bind and affect their member countries to a greater or lesser extent. First of all, the North American Free Tade Association (NAFTA) between the United States, Mexico and Canada, called the Free Trade Treaty by the Mexicans is of particular significance. This agreement has set up the largest economic area in the world, a position previously held by the EEC. One must, however, wait to see how things turn out during what promises to be a difficult implementation period, bearing in mind that the differences between the economies and societies of the member countries are greater than is the case between EEC countries.

In the centre of the American continent there is the "Andean Pact" which includes economies with significant levels of development, such as Colombia, Venezuela and Peru. In the South, "Mercosur" includes countries such as Argentina, Brazil, Chile, Paraguay and Uruguay, which have great potential, although progress has, however, been very slow up to now.

The problems involved in integrating insurance in the new large regional areas are much the same as those we have found in the EEC. However, a high level of freedom in the provision of services is not provided for in the American Treaties, at least during their early stages.

A particular feature of the process of liberalization that several Latin American countries have embarked upon is that it finds its inspiration fundamentally in Spanish legislation and experience, which is closer to Latin American legal tradition, which is Spanish in origin, as well as being closer to the particular intellectual outlook of Spanish speakers. Thus, Mexico and Colombia, and, to some extent, Argentina and Venezuela, take into account the Spanish system for controlling insurance activities and the Solvency Margin, which is, when all is said and done, an application of the standard imposed by three generations of EEC Directives on Insurance, which leave member States some freedom of choice within certain limits.

As can be seen, the influence of the large regional economic areas is most important in the field of insurance. And it will become even more important in the future.

One should not forget that several Eastern European countries, which have recently become democratic, have already stated their intention to apply for membership of the European Union. In spite of all its difficulties, the EU remains an attractive project, one of the advantages of which is that, with more or less difficulty, it is a project that overcomes nationalism and, above all, micro-nationalism. 
The EEC, developed in one way or another, is the only operative way of successfully uniting Europeans. It cannot be overlooked that the European Union has a number of genuinely important achievements to its name: 1) It has succeeded in neutralizing the traditional antagonism that existed between Germany and France, as a result of which it could be argued that it has prevented a Third World War; 2) It has put an end to Spain's isolationism of the last two centuries; and 3) It has brought the United Kingdom closer to Continental countries.

\subsection{The collapse of the socialist planned economies and the general acceptance of the market economy}

The removal of the symbolic Berlin wall and the collapse of the socialist planned economies, together with their dictatorial communist regimes, is probably the most important political and economic event to have taken place during the second half of the 20th century.

The outcome of this, which is by no means any less significant, is that for the first time in history, democracy and its essential economic consequence - the market economy - have come to be accepted everywhere as the only systems that can guarantee economic development in freedom, real well-being and wealth for the people.

The idea that the State should look after individuals from the day they are born until the day they die - which, of course with major differences, also lies behind some European Social Security systems - in exchange for which the State requires that individuals pay the high price of giving up their freedom, is an idea that has been dealt a mortal blow, now that Russia has been converted to capitalism. I do not say that this idea is dead and gone, as this will not be the case until Russia and other former communist countries consolidate their democracies and their market economies after a difficult transition. Moreover, even in Western European countries, there is public and even private resistance to the devolution by the State to Society of many of the numerous and often excessive functions that have been taken on by the State, in Spain and in other European countries.

A "White Paper" recently published by the Commission of the European Communities contains a piece of information that goes a long way to helping to explain the lack of vitality of the European economy. It states that, while the public sector accounts for no more than $32 \%$ of GDP in Japan, and is around 38\% in the United States, it attained $51 \%$ in the EEC (twelve) in 1992. In strictly doctrinal terms, one could talk about Europe, or more exactly a Socialist Community, even though the consolidated democracies in the EEC are not in any way comparable to the former communist countries.

The same publication, using figures provided by the OECD, shows that the level of taxation in the EEC is somewhere above $40 \%$ of GDP, 10 per cent higher than in Japan or the United States.

On a much smaller scale, signs of such resistance against taking the idea of a market economy the whole way in Spain occur, for instance, in connection with Social Security, which is run as a monopoly by the State or, even, among private insurers themselves, where there is a tendency to be neo-interventionist and an apparent increase in the control by the authorities and in new legislative projects. There is still a long way to go before the fight for the responsible freedom of companies can be won.

Satisfactory progress has, however, been made in other countries. As a result of the universal acceptance of the advantages a market economy has to offer over any other economic 
system, both the former communist countries of Eastern Europe and Latin American countries - which are closer to home as far as Spaniards are concerned - are changing over to democratic systems to an unprecedented extent and above all, new legislation is being introduced aimed at liberalizing the economy and in particular, the insurance industry. I am proud to be able to say that UNESPA, the Spanish Association of Insurance Entities, has been working steadfastly in this area, through FIDES and its sister Associations in Latin American countries and, sometimes, in direct contact with the authorities of some of these countries.

One consequence of the disappearance of the confrontation between the First and Second Worlds that existed for four decades is German reunification. This has led the German Federal Republic, in the past a major investor in other countries, to turn into a country that prefers to invest in the other Germany and which keeps interest rates high in order to stimulate its domestic savings and even to attract foreign savings.

Other countries with high savings and investment levels have also been attracted by the countries of Eastern Europe, where they can find cheap skilled labour, a need for industrial and technological equipment and government support for foreign investment.

This, together with other factors has, had an impact on other European countries which have traditionally been poor savers, such as Spain. Evidently, the effect of this is felt in the development of insurance.

The direct consequence - quite apart from the economic crisis, which also has other components - is a slowdown in economic growth and therefore in insurance. One cannot insure business that is not created, buildings or ships that are not built, or expansion of activities that are not undertaken. Furthermore, arson is encouraged and insured companies disappear. A consequence of these developments is the spectacular increase in the number of life insurance policyholders who are asking to be paid the surrender values of their policies. This particular trend had a significant effect on the overall figure for life insurance premiums collected in Spain in 1993.

There has been another unavoidable consequence. While the amount of insurance on offer has remained the same or has even increased, demand has fallen, or at least slowed down. This has led to increased competition as the absence or decrease in new business has forced marketing networks to turn towards insurance contracted by other insurance entities.

\subsection{Structural economic crisis}

An analysis of the Leontiev input-output tables of any country with a market economy over any period in time shows that insurance and banking are the two activities that provide and receive services from all the other sectors of the economy. For this reason, there have been people who have gone so far as to say that if you want to know how any economy is doing, take a look at its insurance industry.

Although no sector of the economy has no contact with insurance, it should be pointed out that there is a certain time lag between economic development and its reflection in insurance, because of the fact that premiums are paid in advance and because keeping up one's insurance cover becomes even more important during crisis periods.

Furthermore, it is well known that under Engel's Law, life insurance grows faster than disposable income. Something similar happens in property insurance, under the principle set out by the Geneva Association on the vulnerability of the economy, according to which 
every new stage of development brings with it an even larger increase in risk. This therefore means that demand for insurance coverage will grow faster than the economy.

Moreover, crises or even boom periods affect different classes of insurance in different ways. In some cases they boost insurance and in others they hold it back. This means that some effects cancel each other out and reduce the overall effect. For instance, crises are bad for Fire Insurance, because there are fewer new premiums, but they lead to an increase in credit insurance business.

Quite apart from the economic situation, which undoubtedly is important in the present economic crisis that is affecting EEC countries to a greater or lesser extent, one should realize that, in spite of biaised political declarations, the present economic crisis in Europe shows very clear signs of being a structural crisis.

For example, if we take $1972=100$ as our base line, we find that by 1992 , the working population in Europe had increased by $10 \%$, while it had grown by $20 \%$ in Japan and by nearly $40 \%$ in the United States. There is no doubt whatsoever, that the combination of biometric and economic components that explain the reasons for this trend can be classed as structural.

Much the same can be said for unemployment rates. Between 1982 and 1992, unemployment remained stable at around $2 \%$ in Japan. In the United States the rate remained on average around $8 \%$ of the working population, whereas the rate in the EEC has always been at least two per cent higher than in the United States. The fact that these trends have continued to be valid for a whole decade are a clear indication that they are structural in nature.

When one looks at inflation, one finds that since 1982 the EEC rate has constantly been between 2 and 3 per cent higher than in Japan and, except during the period 1987/ 1989 , it has always been higher than inflation in the United States.

We could give many other examples, also contained in the White Paper. However, the examples we have given here are all we need to show that in the current economic crisis, with variations in different European countries, there are elements of structural rigidity which with out any doubt are going to have an effect on economic activity in the future and will therefore affect insurance business.

\section{Factors affecting the future of the insurance business: The insurance environment}

In the previous section we have analyzed a few of the very many economic and political factors that have a more or less direct impact on insurance business.

As well as these factors, there are other factors of quite another nature which in some cases, such as monopolies or prohibitions, have a determining effect, and in others simply impose conditions, albeit directly, on the particular activity carried on by insurance companies.

\subsection{The crisis in the State-run Social Security systems in Europe}

A study by the Union of Industries of the European Community shows how the Social Security systems in the EEC are, on average, a heavier burden on business and employment than the systems used in the United States, Japan and Canada.

The key elements for judging a national Social Security system are, on the one hand, the system of financing, which may raise funds either fundamentally from taxes, as is the 
case in Denmark, or for the most part from employers' contributions (Portugal, Spain, France and Italy). Furthermore, although Social Security systems in Europe are normally run by the State, the second important element concerns how such systems are run. They may be privately run, as in the case of Health in France or Pensions in Ireland, or may be run as a monopoly (Spain, Portugal, Italy).

Perhaps the factor that has made State-run Social Security systems unable to cope is the so-called unemployment benefit.

The economic crisis affects Unemployment Insurance in two ways. When somebody loses his job, the Social Security loses a contributor, i. e. there is one person less paying into the system. But at the same time, it acquires an extra beneficiary, i.e. one more person is receiving money from the system.

The result of this is an increase in the technical shortfall of the social security budget.

One of the causes of the crisis in the social security system relates to the health care system. Health care costs are increasing geometrically in all countries. People are living longer, which means that there are more senior citizens who are major consumers of health care services. Treatment has become more expensive as a result of progresses in medical science and because, when demanding health care for oneself, everyone becomes intransigent. This makes expenses grow like a snowball rolling down a snowy hillside. Moreover, the inefficiency inherent in any monopoly, made worse by the fact that it is a State monopoly, leads to congestion in the system, with cases where people have to wait for up to six months or even a year for certain operations ; levels of occupancy with beds filled even in hospital corridors, that are much higher than those recommended by the World Health Organization.

This lack of satisfaction with the way the State runs the health services has caused popular reaction and is giving rise to official reaction, in Spain at least.

Indeed, around six million people who are contributing to the Social Security system have taken out voluntary Health Insurance, basically in order to receive faster and more personalized medical care. The problem is not that the doctors are not good enough, because the doctors who work for the public health care system are very often the very same ones who are working for private insurance companies. However, the fact remains that six million people in Spain are paying for the same thing twice over, which clearly constitutes economic inefficiency.

A clear example of the generalized dissatisfaction with the State health care system is the Civil Servants' Mutual Company, MUFACE, which is the only collective service that is legally entitled to choose between public and private systems, where a majority that varies between $90 \%$ and $95 \%$ of civil servants themselves have been constantly opting for the private system.

For the first time in many years, the authorities appear to be showing some interest in the collaboration that private health insurers can offer the State system. This might lead to a certain weakening of the monopoly-control over the running of the system. The Director General for insurance, who heads the body that controls insurance in Spain recently made a statement along these lines.

Were this new trend to be confirmed, the Spanish system might be able to become more like the system in France where, on the basis of the so-called "moderating ticket", the private sector provides the services of the public health care system. 
In any case, the greatest burden on the economy is the system of pensions of all kinds (retirement, invalidity, widows, etc.).

Pensions in Spain, like in other countries, are affected by developments in living patterns. The first of these is the dramatic fall in the birth rate and the second, entirely favourable, is that people are living longer.

Another decisive factor is that State pensions are financed on a participating (you-payas-you go) basis, which does not create savings, unlike systems of capitalization, such as Life Insurance and private pension schemes which first save and then spend.

The combination of trends in living patterns and the system of participation has had the following consequence: there are going to be fewer and fewer young workers to pay, just when there are going to be more and more old age pensioners than ever. Moreover, these old people are going to live longer and therefore spend many more years being paid by the system.

A corollary to this fact is that old people, who have not saved under the system of participation, will have made no contribution whatsoever to the sort of investment that creates jobs for young people. This situation may lead to what some authors have called a "generation breakdown".

The process is speeding up along two lines: early or tolerated retirement, to find solutions for problems other than those planned for the benefits: restructuring of companies, union pressures, stimulating employment among young people, etc. and, above all, noncontribution pension schemes, i.e., in favour of people who have not contributed to the system. The number of pensions in Spain has been growing at more than $5 \%$ for many years, apart from the revaluations of pensions to maintain the purchasing power of pensioners. All these factors have made the cost of retirement pensions sky-rocket.

The other factor that is speeding up this process is the transformation of retirement pensions into invalidity pensions, for the very same reasons as have just been explained, as well as for the following reasons: lower taxation and full pension without calculating the number of years of contribution. This would result in lower averages. This particular phenomenon led to the absurd situation that, at a given moment in time, the number of new invalidity pensions exceeded the number of new retirement pensions, leading Mr. Almunia, who was then Minister of Employment to say that, according to these figures, Spain was "a country of cripples".

If the financing system had consisted of State contributions charged against taxes, it could be assumed that these perfectly well-known irregularities would not have taken place, at least not on such a massive scale. However, although political advantages are gained by the Government of the moment, and the cost is paid by companies, it is easy to prefer to attend to other matters and even, as happened when the Spanish Business Organisation, the CEOE, complained about fraud in cases of temporary incapacity to work, to cut down the number of inspection against fraud and other omissions, probably based on the psychological principle which states that "everyone is free with other people's money".

This huge increase in pensions, which has now been halted to a certain extent, together with the pathological phenomenon of job destruction in Spain, i.e. a reduction in the number of people who are contributing to the system, has resulted in a ratio of 1.5 contributors for 
each recipient, probably the lowest in Europe, and a cause for concern. Every three workers are paying for two pensioners. And, given the age pyramid, this ratio will in all likelihood fall even further.

This situation has led the present Ministry of Economy and Finance, Mr. Pedro Solbes, to say, to the hypocritical scandal of many, that the Spanish pension system, in its present form and if no corrective measures are taken, will become unworkable by the second decade of the 21 st century.

The author of this work, in a speech given at the prestigious XXI Century Club in 1984, said almost exactly what Mr. Solbes has just confessed, ten years later. Of course, when one looks at what politicians had to say, this warning, as well as the recommendation that the longer it took to change the situation, the higher the social costs, was not only not listened to but also attacked by some people as "doom-mongering" and "destabilising". However, it is revealing and comforting to know that the actuaries working for the Social Security at the time agreed with this diagnostic (off the record, of course). This means that the people who run the Social Security system have always had access to the correct figures.

Political factors once again predominated over economic considerations in the Pension Schemes and Funds Act, Law 8, in June 1987. The aim of this Act could not be more proper and timely. As stated in its Preliminary Section:

"Although the social purpose which Pension Funds must fulfil above all others, which is to facilitate the future well-being of the retired population, must be stressed, one must also realize the importance of the effect that the implementation of such an objective may and has to have in financial terms. The experience of other countries where Pension Funds have become well established, point to the fact that they have the effect of stimulating longterm savings.

However, such objectives have to a great extent been thwarted, as a result of various different limitations.

First of all, the stinginess of the tax advantages - limited to Ptas. 500,000, and then increased to Ptas. 750,000 , which is only beneficial to young people as this limitation means that people over 50, who have the greatest need for this Act, are virtually left out.

Secondly, there was too much union intervention in the employment plans. This has meant that they have been a virtual failure.

Furthermore, defined-benefit plans, which are without any doubt really a form of life insurance, to the EEC Directives on Life Insurance, by frivolously playing with the meaning of words, are not covered by the Act.

As can be seen, the crisis in the pension systems operating under systems of participation and the rigidities of various kinds in the Pension Schemes and Funds Act, show that there is a need for major changes to be made, as well as for making use of the experience and technology gained by private insurance and, of course, to submit to the strict solvency controls laid down in EEC and Spanish Law, to protect the insured.

There remains the problem of the transition, which should not be too abrupt, and of financing the undertakings entered into by the State with contributors, which have not been guaranteed so far, not even partially, by any kind of mathematical reserves.

The solution of the difficulties of the Social Security system depends on whether they can be approached correctly, especially as regards pensions, in order to bring our system 
closer to the system used in Ireland. It is not by chance but rather because of the way its Social Security system operates as regards privately managed pensions, that Ireland has the highest level of life insurance premiums per capita in the world, while its per capita income is much the same as in Spain and far lower than in Switzerland, Germany or the United Kingdom.

\subsection{The liberalization of legislation}

The triumph of the market economy ideal, the liberalizing current stemming from the Treaty of Rome, the demands imposed by international financial bodies on countries with large foreign deficits, the trends in services recommended in the Uruguay Round of GATT talks and the way the markets themselves have developed, among other factors, have combined together to add strength to a current of liberalizing legislation in the fields of finance and insurance, sometimes called "deregulation".

Deregulation is not exactly the right term to use, because this trend does not involve the removal of existing legal regulations, with their interventionist rules, in order to create a legal vacuum or absolute freedom. What has happened is that the interventionist legislation, full of permits, controls and rigidities, has been replaced by a different, more liberal, more competitive set of rules, which focuses more on the essential aspects of control (solvency in insurance, liquidity in the case of financial intermediaries, measures to protect competition in all cases). Pushing things somewhat, the most we could say is that there has been partial deregulation.

In the European Community, the regulations laid down for insurance have forced certain monopolies to be dismantled, such as the Caisse Centrale de Réassurance in France for example, or the Istituto Nazionale delle Assicurazioni, in Italy. All Companies had previously been obliged to cede part of their premiums in their respective markets (in the INA's case, only for Life Business). In Spain, the Consorcio de Compensación de Seguros has been privatized, which has made it something less of a monopoly. It should be added that the Consorcio's role in relation to catastrophe risks is highly appreciated by insurance entities.

One consequence of the EEC legislation is that discrimination of any kind on the grounds of nationality has been eliminated between citizens, including legal entities, of member States. It has been commented that the process of nationalizations embarked upon in France in 1946 was not carried through to the end, because France, a founder member of the EEC in 1956, was required to treat foreign private insurers from other member States operating in France in the same way as the State-controlled French companies that would have been created as a result of the second nationalization.

The current centre-right Government in France, which scored an overwhelming victory in the elections, has decided to privatize the French State-owned insurance companies which were nationalized in 1946.

In Spain, insurance companies that are owned by the State or by other public bodies or State companies compete on the market without any special privileges. In UNESPA's experience of more than 17 years, there has never been the slightest difference of opinion as regards measures taken by State-owned companies, whose managers have a competitive turn of mind that does not differ in any way from that of all the other private entities. 
When it comes down to it, the matter of ownership has no importance in the market, as long as State-owned companies are left free to manage their own affairs and are not granted any special privileges. This is why there have been some differences of opinion on specific matters relating to the Consorcio de Compensación de Seguros, although not as far as the general idea is concerned.

\subsection{The increase in international competition}

It is very clear in the EEC that the liberalization of legislation and the absence of any kind of discrimination between persons or entities from different countries of the European Union has led to an increase in the presence of insurers from other markets in each of the domestic markets, which has brought with it an increase in international competition. The term international competition has been deliberately used here, instead of intra-community competition, because of the fact that several hundred companies that are controlled by owners from outside the EEC qualify as EEC Insurance Companies.

The appearance of the first draft versions of the second generation of the EEC directives, which referred to the free provision of services, led large European companies to adopt a new policy of becoming present in other EEC member States.

This might seem a contradiction since the freedom to provide services means that companies can operate from their home offices of from one of their branch offices in a third country without having to set up an establishment. However, there has been an increase in the number of companies purchased in other countries. Apart from the general reasons that make it advisable to spread risks and to offset profits and losses against each other, apart from the improved service to industrial and service company customers, who are becoming increasingly multinational, perhaps the underlying reason for this trend lies in the fact that the Single Market does not apply to taxation (except taxation on insurance contracts) and that premium rates are not the same everywhere, but vary from one market to the next depending on each market's experience, and that the contents of policies are not the same, as regulation governing insurance contracts has not been harmonised.

This is why, as mentioned earlier, a Company that is present in 16 member States can make its customers 16 offers, subject to 16 sets of law and, above all, with 16 widely varying sets of tax rules. On the other hand, a Company that only operates in one domestic market or which only operates in other markets by using its freedom to provide services, can only offer the terms of its own country. By entering other markets, such companies can offer competitive advantages, especially for large risks.

British insurance, for instance, has large companies that operate in a number of different countries. It has in the past tended to expand into Commonwealth countries. The fact that it was not present in other EEC countries has forced it to change over to a new policy aimed at expanding its presence in such countries. British and Dutch companies have carried out major acquisitions in the Spanish insurance market, where there was previously very little British presence and no Dutch presence whatsoever.

Brokers have also increased their importance in the market, reducing the protagonism of insurance companies from each country.

First of all, small broking firms have been taken over by "megabrokers", mostly American or British, who have very extensive international networks. Until businesses became free to provide services across borders, very large risks managed by brokers had to be 
placed with one or more companies of the country of the risk. Such companies, with or without the broker's assistance, place surpluses with reinsurers. This was the legally applicable system even though it was sometimes got round by the what were called "fronting companies" who only retained a symbolic part of the risk and reinsured virtually all of it thus acting in fact as intermediaries rather than as insurers. However, now that the freedom to provide services has become applicable for co-insurance in the EEC, brokers may legally place risks directly in either the market of the country of the risk or in any other EEC country, without having to place it with domestic insurance companies. Furthermore, the international networks of such megabrokers (which most domestic companies do not have) enables them to do this and gives them an obvious advantage.

In this way, in addition to the increased competition resulting from the larger presence of insurance companies from other countries or else their subsidiaries, there is now also more competition arising out of the freedom to provide services, either by companies taking the initiative from their own countries or because of initiatives taken by brokers in the actual country of the risk. Furthermore, the third directives actually allow the application of a system of greater freedom, even when an agent or broker is dealing with the insured.

Finally, as I have already mentioned, there has been an increase in the number of Spanish companies that have been acquired by insurers from outside the EEC with the aim of setting up in the EEC and enjoying the advantages of non-discrimination and freedom to provide services that go with their formal status as EEC insurance companies.

\subsection{New financial products and "bancassurance"}

According to Professor Denis Kessler, if we divide the figure for "banked market" by the figure for "bankable market", the resulting figure is nearly one, because of the high level of penetration of banking in society. If, on the other hand, the same division is calculated using the figures for "insured market" and "insurable market", the result is a lot lower. In Spain, this figure is thought to be less than 0.50 .

This saturation of the banking market has coincided with a period of "banking disintermediation", as a result of the growing number of new types of legal entities and finance companies of all kinds.

One can add to this that the crisis in the State pension system financed using the method of participation and the option of insurance and pension funds based on capitalization, offer very real growth potential which increases the intrinsic expectations of insurance business. All this explains why credit institutions (Banks and Savings Banks) are taking an increasing interest in insurance. Until this concurrence of factors came about, the interest of credit institutions in insurance focused chiefly on administering Insurance Companies' investments and in the possibilities of placing security issues guaranteed by credit institutions with insurance companies.

There have been three episodes in Spain relating to the relations between banking and insurance: the subject of savings bank-insurers; the unfortunate case of single premiums and the current collaboration where the insurance company provides insurance and the bank acts as intermediary.

In 1986, for reasons relating to Spanish domestic politics, certain Savings Banks in Catalonia were authorized by law to operate as the same legal entity as insurers who take on risks. 
UNESPA opposed this authorization, and filed two types of appeals: one with the Spanish courts (this appeal was successful) and a complaint to the EEC Commission.

This matter was of huge significance for Europe, because, if a Spanish savings bank could operate as an insurer in Spain, under the doctrine of the European Court as laid down in the "Cassis de Dijon" case, it would be able to operate as such in all the other EEC countries where such joint activities are strictly prohibited.

The European Commission ordered the Spanish Government to derogate this authorisation, because it was in breach of the principle of speciality set out in the First Life Directive and, in the end, the Spanish Government bowed to the criterion of the EEC and withdrew its authorisation, even before UNESPA won its case in the Spanish courts.

It therefore became clear that credit institutions could not operate simultaneously in insurance business using the same legal entity as for their credit operations.

The case of single premiums is different and did not have such a happy outcome. When the so-called "afros" (financial assets without withholding at source), which it was said was where money not declared to the tax authorities was being invested, ceased to be opaque for tax purposes, certain savings banks discovered that Life Insurance was also opaque and by means of an ingenious system of single-premium insurance policies, the opaque nature of the "afros" was created once again. Other financial intermediaries, who owned insurance companies, worked along the same lines and single-premium life insurances attained incredible figures in the accounts of insurance companies that were subsidiaries of banks or savings banks. The Ministry of Finance reacted strongly and carried out tax inspections of the companies and set in motion a populist campaign in the press as a result of which insurance came to be regarded as an instrument of tax fraud, which had little to do with the real situation or the mainly instrumental role played by the insurance companies. But as we know as far as politicians are concerned what "appears to be" is what "is".

The case of single premiums was also to a great extent a driving force behind another undesirable repercussion: the despecialization of insurance. Despecialization means that in order to overcome the complexity of insurance, some sectors of the Public Authorities decide that it would be a good idea to regulate it in exactly the same way as banking, which is much easier to understand. This has led to notable distortions in application, bearing in mind that insurance is something more than simply the financial aspect and that Insurance Law, as a specific activity, has had its own specific legislation for more than five hundred years.

We believe that the reasoning of UNESPA, the Spanish Association, has gone a long way to help to recover the specificity of insurance. This is no minor matter, nor is it confined to Spain, as the European Insurance Committee has had to constantly argue with the EEC to prevent the control of financial conglomerates which have credit institutions and insurance companies, being exclusively the control designed for financial institutions.

Looking at the regular collaboration between banking and insurance, that has been given its French name "bancassurance", it is clear that there is a reciprocal interest in working together, because of the complementary nature of the two types of business.

For an insurance company the files of bank customers is practically a list of all citizens with a certain purchasing power, that is far more complete than any list that can be made by traditional networks of agents and brokers, at least in the short run. The large number 
of bank branches that have been opened in all centres of population of any significance, confirm the importance of banking networks for marketing insurance products, especially for life insurances that are easy to explain and easy to understand. Technical staff from an insurance company or the professional insurance agent are still needed for more complex covers. Moreover, the overall financial advice, even on tax matters, is a competitive advantage of cooperation between banks and insurance companies.

As for banks, acting as an intermediary in a growing business like insurance and pensions, the new services offered to its customers, the possibilities of selling its financial products, complementary to pure insurance products, through the networks of agents of insurance companies, constitute recognised attractions for credit institutions. This is in addition, of course, to the traditional advantages in matters of investment management.

There is undoubtedly a certain incompatibility between the technical, legal, marketing, etc. cultures which have only really been overcome in the Netherlands, in a manner that is not easily understood in other European countries. However, considerable progress is being made towards achieving a symbiosis between the two activities, which bodes for significant development in this field, although maybe not as much as some people want and others fear.

It is probably a good idea to make it clear that the experience of the countries that are the most advanced in insurance shows that, although any present or future sales channel should be exploited as far as possible, selling through agents and brokers is the typical method used by insurance and still is, in spite of everything, contributing to the largest proportion of business underwritten by general insurance companies.

\subsection{The generalized technical losses and the fall in interest rates}

If financial income is not taken into account, for every 100 pesetas in premium income collected in Spain for non-life business in 1993, insurance companies have paid 106 pesetas. Two years ago, they paid 110 pesetas, according to the preliminary statistics drawn up by UNESPA.

Using another source of statistics, the Book of Balance Sheets and Accounts published by the Directorate General for Insurance, in 1992 there was a technical loss of $10.54 \%$ of premiums, somewhat better than the $12.10 \%$ deficit recorded in 1991 . These figures include the sum for the whole sector. (Statistics prepared by J. I. Guerrero).

The technical shortfall of premiums to meet expenses that this necessarily entails (loss ratio plus reserves, internal management expenses and external management expenses) is not the result of the situation in 1992 and 1993. It is an entrenched result (for Non-Life businesses, evidently) in Spain, and also in other European countries, to a greater or lesser extent.

Over-supply, the contraction of production as a result of the economic crisis and certain particular dumping practices which have on occasions caught up traditional conservative companies are the causes that can be put down to this long-standing trend of technical losses.

Three types of dumping have been observed in Spain. Firstly, aggressive dumping, practised by some companies that are prepared to lose money in order to increase market share. The Chairman of a major foreign insurance company has made statements that his company intends to pursue such practices, without any reaction having been observed either from the authorities or from the private sector. 
As a result of and in reaction to such practices, one sometimes finds cases of reactive dumping, which has sometimes been practised by serious traditional companies, in order not to lose certain portfolios.

Finally, there have been cases of innocent dumping, which may be practised by entities that are not sufficiently equipped, or when insuring risks for which there is little or no statistical information.

In view of such a sustained trend, the logical question that arises is how can it be that a market fails to react or, at least, fails to do so more forcefully, under the pressure of reinsurers.

The answer is also obvious: because ordinary and extraordinary financial results are rigged, so that technical losses are wiped out and even so that a small technical-financial profit can be recorded.

The problem is that, on occasions, such financial income is not the result of normal returns on investment, redemptions of fixed-income securities, etc. Instead, they are made by pursuing a policy of selling off assets, which must inevitably reduce the entity's solvency, even though it continues to record profits every year. The realisation of assets is an acceptable method of dealing with particular economic situations but should never become a sustained policy used to finance profits that are not the result of the business.

The first thing that must be said is that the Companies have reacted individually by adopting measures in those aspects where they are able to take decisions, wholly or partially, by themselves: internal and external management expenses. However, they have not taken any noticeable action (except in Motor Insurance) with regard to the aspects that depend on the market as a whole, such as premium levels, policy terms and, to a certain extent, agents' commissions.

In effect, in Non-Life Insurance businesses, the ratio of internal management expenses to premiums has fallen by 1.1 per cent over the last five years. Likewise, external management expenses have also fallen, by 1.9 per cent between 1989 and 1993.

As a result of such measures and of an improvement in claims frequency figures in Motor Business, the technical shortfall in Non-Life insurance was $6.6 \%$ in 1993, an absolutely unsatisfactory figure, even though it is an improvement on the technical loss recorded in 1989 , equal to $12.6 \%$ of premiums.

The problem that has arisen in 1993 and which has been consolidated in 1994 is that financial returns have fallen significantly and will continue to do so, as a result of the measures taken by the Government to stimulate the economy, the reduction in interest rates following on the devaluations of the peseta and the fall in interest rates in other countries which necessarily have an impact on how EEC countries implement the directive on the free flow of capital.

The significant reduction in the "manna" of financial income throughout the whole of Europe has meant that insurance entities must seriously consider changing the pricing policy pursued up to now, as well as being stricter in their observance of actuarial rules, and pursuing a policy of risk prevention which would help to reduce the loss ratio. This is the only possible logical reaction. And, what is more, these measures need to be adopted by all the insurance entities. 
At this stage, it is worth taking a look at the EEC system for protection competition.

To begin with, the EEC started out from the erroneous, albeit understandable, assumption that insurance should be subject to Article 85 of the Treaty of Rome and Regulation number 17, and not be treated separately at all. All of the Business Associations in Europe sent the D.G. IV tons of documents so that it could check on whether certain agreements that had been taken collectively were likely to represent restrictive practices.

As a result of these documents, which showed that there were no significant monopolies or collusive practices in Europe, and the dialogue with the European Insurance Committee, the Commission understood that the need for common statistics, in fact, the application of the rule of large numbers, was an essential technical condition for insurance premiums to be fair and not attack the solvency margin, which is the guarantee of the insured.

This led the EEC to publish the Regulation of the Council EEC/1534/91, of 31 May 1991, concerning the application of Article 85 Section 3 of the Treaty of Rome to certain categories of agreements, decisions and collusive practices in the insurance industry.

It is therefore possible, from the point of view of the rules that protect competition in the EEC, to encourage joint reactions, as regards the statistics that are used as a basis for calculating risk premiums, aimed at restoring the loss ratio that has suffered from too much competition that has failed to follow actuarial techniques.

In Motor Insurance, where losses reached scandalous levels, there was a collective reaction which, combined with the preventive measures taken and close collaboration with the Traffic Authorities in Spain, has enabled performance to improve considerably, without having to increase premium rates out of all proportion.

The Technical Committee of Property Risks at UNESPA is leading a movement in General Public Liability Insurance which is recording heavy losses, and in certain cases in multirisk insurance (where the loss ratio is growing and internal and external management expenses are too high, mostly because of the low price of premiums), which has been welcomed by insurance companies, aimed at restoring a policy of consensus in the reality of the market regarding the combined ratio. The results achieved in Motor Insurance are a stimulating example.

Although I know that what I am going to say now is nothing new, I feel I must stress that Spanish and foreign reinsurers, in their own interest and in the interest of their ceding companies, should put pressure on the ceding companies, both individually and collectively, to persuade them to adopt the measures that are needed if they are to record technical profits.

\section{Other factors affecting insurance business in Spain}

After making an attempt to isolate some of the very many factors, be they of a general political and economic nature, or relating to the insurance environment, the design needs to be completed with a few other conditioning factors that must necessarily be looked at by anyone who wishes to reflect on the future of insurance and, if need be, on the microeconomic strategies of his own company. Some of these factors affect insurers. Others, without doubt the most important, affect the insured.

\subsection{The inadequate tax treatment of Life Insurance}

Although it is unlikely that any insurer in any country is satisfied with the tax treatment 
it must bear, in Spain there is a series of specific circumstances which stem from the fact that the State has given priority to collecting revenues and as a result of the fact that there is no policy that encourages saving, as a basis for investment to create jobs. Collecting tax revenues takes precedence.

To start with, one must mention the fact that taxes have risen in Spain faster than in any other OECD country. It can be said, with complete exactness, that Spain holds the Gold Medal for tax effort.

The Ministry of Finance minimises the notion of tax effort and stresses the fact that the tax burden in Spain is still lower than in other European countries.

Both positions are true. What is happening is that there is a contradiction in the position taken by the Tax Authorities. In effect, both the Spanish Constitution and its tax laws enshrine the principle of progression, according to which higher incomes pay a higher rate of taxation than lower incomes.

If this tax principle is accepted and is even extolled, because of its social character, one cannot, for exactly the same reasons, compare the tax burden with that of other countries which "per capita" incomes that are in some cases $50 \%$ higher than in Spain.

What is clear is that over the last decade the public sector has grown without interruption and the private sector, as well as having to suffer the effects of economic crises, has had to bear the extra burden of a disproportionate increase in taxation.

To be sincere, the tax treatment of life insurance in Spain is comparable to that of other EEC countries as regards certain aspects (e.g. premiums) and is considerably worse in others, especially in connection with the insured (deductions from personal income tax, successions, etc.), in spite of the fact that life insurance creates long-term savings that grow like a rolling snowball, which are particularly ideal for sustained savings and long-term investment, which is the only type of investment that creates employment, as one learns from the most basic book on economics.

History shows us how some of the tax advantages granted to policyholders under the previous legislation have been sacrified on the altar of tax collection. At the same time, certain financial products (Investment Funds or Pension Funds, for example) have been given tax stimulants, in some cases higher than those allowed at any given time for life insurance policyholders.

Regardless of the fact that the insurance sector feels that it has been treated unfairly by what it regards as unjustified discrimination, and quite apart from the fact that such practices can be judged to go against economic rationality and the Government's repeated priority of creating jobs, the continued reduction in or loss of certain savings stimulants for life insurance policyholders, the problem that arises is, furthermore, of macroeconomic importance on a large scale, in relation to intra-community competition.

In effect, as is known, on the one hand the EEC is going to embark upon a process of tax harmonisation, with the exception of VAT, as a basis for financing the States of the EEC itself. On the other hand, as the tax system of each country in the Union remains in force and insurance policies may be sold in other countries, under the tax system of the country of origin (except as regards insurance contracts), it is inevitable that a competition between tax systems will appear between the different countries in the European Union. 
Indeed, every country competes with other countries not only through the microeconomic productivity of its businesses but also - and above all, as far as life insurance is concerned - through its system of taxation. This has obvious consequences: savings are going to start delocating, perhaps not straight way but gradually, away from countries with heavier or more transparent taxation, towards more liberal countries, with systems of taxation that stimulate more saving or are more opaque. The freedom to provide services and the free flow of capital will make this easy.

Governments that are more sensitive to international competition have reacted by what is called in EEC jargon "competitive defiscalisation". This means, the modification of a country's own system of taxation, either to prevent its own savings from moving out of the country, or to attract savings from other countries. The fact that Germany has significantly reduced taxation on its companies could be taken not as a gratuitous action on the part of the Government, but rather as a method of stopping German companies from being set up in Luxembourg.

Therefore, either one thing or the other. Either Spanish tax legislation is modified to bring it into line with the average for EEC countries, or one runs the risk that Spain, a country with insufficient savings, that finds that it has to base its development on importing foreign capital, simply because of its desire to collect taxes in the short term, sees part of Spanish savings leave the country for more welcoming markets.

As usual, this possibility is played down using arguments that are formally correct but really inoperative. Here is an example of what I mean.

The "reformatio in peius" of Spanish inheritance tax, as regards insurance, introduced two hitherto non-existent requirements : to include the Insurance as part of the estate and to take the heirs prior wealth into account when setting the rate of tax. Life insurance, which had previously been taken out to pay the taxes and leave the inheritance, often a small industry, free of charges, i.e. respecting the production units, is no longer taken out because it makes the heir's situation worse.

As this does not occur in other EEC countries, it is clear that a knowledgeable insurable person can take out Life Insurance in, for example, Luxembourg or in another EEC member State, without the Spanish tax authorities knowing anything about it. The tax authorities rightly argue that when the heir who has received the entire inheritance files his income tax return, he will have to declare this increase in his income in Spain. Although this is true, if the Spanish tax authorities have absolutely no knowledge of this insurance and the heir does not declare it, the tax inspectors will not be able to detect it. The Spanish tax authorities could of course ask the tax authorities, in this case, of Luxembourg to give them the names of the Spaniard policyholders who have taken their savings to Luxembourg and of the beneficiaries who have paid the low rates of tax in Luxembourg, as a result of which they have been benefactors of Luxembourg who will hope that other Spaniards act likewise. There is little chance of the Spanish Authorities getting a positive reply or efficient collaboration, bearing in mind that this is a subject where the EEC has no authority to intervene and remains within the exclusive competence of each member State.

The Spanish taxation of Life Insurance was already a cause for concern before the introduction of the Freedom to Provide Services and of home country control over the insurer. Now that these very significant changes have taken place and have been accepted by 
Spain who voted for them, the problem has now taken on a national macroeconomic dimension with regard to the delocation of savings, in a context of "competitive defiscalisation". And, what is more, it urgently needs to be dealt with.

\subsection{The poor image of the insurance industry}

As much as insurers do not like the idea, the fact is that, for diverse reasons, the image of the insurance industry, unlike what happens for other economic activities who have carefully cultivated their image, such as banking, the image of insurance is paradoxically worse than reality.

The reasons for this are to be found in the legislation on Compulsory Motor Insurance, in procedural legislation, in how certain sectors of the public authorities have behaved in the past and, of course, in the individual and collective errors and omissions of insurers themselves.

For many years, the pricing of Compulsory Motor Insurance policies was subject to the political control of the "Junta Superior de Precios" (Pricing Board). As often happens, the members of the Board had a tendency to keep down the level of price rises in each sector as a result of which applications started being made for much more than was needed so that once the price rise had been brought down, the resulting price was at the correct levels.

This possibility, which was in widespread use in most sectors, was not allowed in insurance, because the Directorate General for Insurance carried out an actuarial study beforehand which meant the premiums could not be charged at higher rates than calculated by the actuaries. As the Pricing Board treated insurance just like any other activity, any "political" reduction in premiums meant that the insurer inevitably made a "technical" loss on premiums. This is the origin of the saying among insurers: "insurance must sell five peseta coins for four pesetas".

As a result of the insufficiency of premiums, insurance companies adopted a harder line, both internally and in court, when settling claims. Although the same practice was not followed by all companies, one has to admit that some companies, that happily have now disappeared, resorted to certain procedural skills, which although they were always legal were not always legitimate.

This led to a worsening of the atmosphere in the courts and not everyone was able to make the distinction between the responsible claims policies pursued by the majority and the irresponsibilities of a minority who were having difficulties in meeting their obligations. This had a double "halo" effect. On the one hand, unfortunate experiences with some entities were extended, without any reason, to the whole industry. On the other, the image of compulsory insurance, which had a large number of policies, contaminated the image of other classes of insurance where there was no social or legal conflict, such as Life, Fire, Individual Accident Insurances, etc., which had always been well looked upon by the public.

The case of single premiums, which we have looked at earlier, led to a campaign in the press, supported by the powerful State media, aimed at putting pressure on insurance entities to give the names of their policyholders (something they unanimously and forcefully refused to do) as well as on policyholders themselves, to make them file the complementary tax returns themselves, and exaggerating things by claiming that insurance companies were conspiring to evade taxes, that they were abetting crimes, etc. Although this Government 
campaign did not succeed in forcing insurance companies to give the names of their policyholders of their own accord, it did receive widespread media coverage, in the press, on radio and on television, since the Spanish Government controls important parts of the media.

This campaign had two negative effects. Firstly, insurance companies came to be associated with the idea of tax evasion. Secondly, a certain amount of hostility, or if you prefer, less comprehension of the difficulties being faced by the insurance industry, on the part of the Ministry of Economy and Finance, which has authority over the insurance. In Spain, the Ministries of Economy and Finance are not separate.

Everyone knows that the main assets of a Credit Institution or an Insurance Entity is its prestige and the trust of the general public. This is why the bodies that have authority over these types of Entities who are, moreover, required to keep professional secrecy, generally tend to be extremely prudent when making statements that might affect the confidence of the general public in this type of Entities.

However, on some occasions, people working for public authorities have made thoughtless statements that have caused alarm, for instance in connection with small and medium-sized insurance companies or regarding a particular insurance entity, which has lost prestige, thus losing agents and portfolios. This is a subject where prudence cannot be overdone, because of the essential value that public confidence has for any insurance company.

Such action has certainly not helped to improve the image of the insurance industry.

Neither are we, as insurers, blameless as regards having contributed to, or at least not having put a stop to, the deterioration of the image of insurance.

Perhaps, the most important action taken to improve our image, which also proved to be a success, was the first one carried out. This consisted of a series of television spots, interpreted by Fernando Rey, which showed factual cases that were resolved by each of the different types of life insurance. Premiums increased considerably, an unexpectedly large number of queries were made by possible policyholders at the offices of insurance companies and the prestigious image of Fernando Rey came to be associated with insurance. For some time, Fernando Rey was Mr. Life Insurance. The logo consisting of a circle of persons hand in hand was also created, as a symbol of solidarity, which was colloquially called "la sardana", and was used in subsequent campaigns.

Fernando Rey was very happy to accept the job, because, as he explained, it was thanks to insurance that he had been able to survive infancy, just after the Spanish Civil War.

This campaign won the FIDES Prize for the best campaign in Spanish-speaking countries.

Inexplicably, the extremely valuable image of Fernando Rey was dropped, and the following action consisted of a series of cartoons which had far less impact.

Subsequent commercial rivalries (because some companies felt that the general campaigns paid for by all were benefiting the insurer whose advertisement appeared immediately after such campaigns), meant that for a long time no further campaigns were possible.

Finally, dropping the logo and without the participation of the UNESPA Committee 
for Personal Insurance, backed by financing from a few of the large companies, who were the only ones really interested, the latest television campaign appeared and went virtually unnoticed.

These days, companies advertise separately and it is felt that, whether one likes it or not, any insurance advertising indirectly favours the industry as a whole. Precisely, Santa Lucía has made a major impact based on the maternal instincts of a huge polar bear towards some lovely white bear cubs.

However, many insurance companies have for some time been investing huge amounts of money in spectacular events that are only seen by their colleagues and competitors.

And the people who run insurance companies established in Spain, with a very few exceptions, refuse all contact with the press. The bodies most inclined to dialogue with the media are UNESPA, through its Press Office, and UNESPA's own Technical Committee for Motor Insurance.

Likewise, with very few exceptions, insurance companies do not appear as protagonists or sponsors of cultural or social events.

On the other hand, UNESPA has been working hard, as the Motor Insurance Committee has been working most efficiently with the authorities, in particular with the Directorate General for Traffic, toward reducing claims affecting persons, which has generated a very positive image for insurance in this field.

Furthermore, the Committee of Property Risk has proposed a plan for working with the Ministry of the Interior to fight against fraud in insurance.

\section{Possible strategies for the insurance industry}

Now that we have seen a broad overview of the factors affecting the insurance business, a purely logical consequence is that the strategy of an insurance company aiming at being successful on the market, i.e. to persuade policyholders to choose it and to achieve customer satisfaction, should focus on taking advantage of opportunities, the numerous opportunities of the economic, political, social and insurance environment, while at the same time overcoming the threats to their business, which are also numerous.

\subsection{High level of competition}

As has been seen, a current feature of the market that can be expected to continue in the future is the extraordinarily high level of competition. This means that any company who wishes not only to hold on to its position, but also to grow and make a profit, must become highly competitive.

The idea of being competitive, like the idea of productivity, to which it is related, has no precise definition. To be more specific, to be competitive, a company needs to focus on price, products and services, among other concepts.

As far as price is concerned, insurance entities operate between the "Scylla" of premiums that must be as low as is technically possible, and the "Charybdis" of making a technical profit that strengthens its solvency margin.

This is the area where the equilibrium should be determined by correct and representative statistical data that offer risk premiums that should be strictly observed, be they the product of statistics of the industry or of one or more companies, with a number of risks 
that is sufficiently large for the results to be deemed representative. Something that is not usually mentioned and which is strictly true is that underpriced premiums mislead policyholders.

On the other hand, entities can make reductions in the commercial premium in the internal and external management expense loadings, by managing and marketing better than other rival insurance companies. Later on we shall refer to how technological progress has helped to improve management efficiency.

Top business organisations, such as the CEOE, can help decisively by working for the elimination of labour rigidities that are an obstacle to the production of companies in general, including insurance companies. The role played by specific organizations in each sector, such as UNESPA, in defining suitable employment policies specifically for the insurance industry and negotiating with powerful unions in order to gain structural advances.

The need to concentrate most of our efforts on reducing expenses as the major element in becoming more competitive arises because the freedom to provide services allows countries from other markets who are operating in Spain to offer their products with their original costs (labour, tax, etc.). Faced with this, Spanish costs, which are slowly falling, are still higher than those in other EEC countries where Unions are not politicised and have a long tradition of working by consensus. Under the conditions involved in Spain being a member of the European Union, the increased competition Spanish companies are faced with, this is no longer enough during the application stage of the third directives.

Another important element in the increase in competitiveness concerns the products.

The Spanish market, as a result of increasing competition and because of the fact that the foreign companies that have started operating in Spain have brought in different products, especially life insurance proclucts. Moreover, as is to be expected in an open market, the most successful products are copied immediately by rivals.

One of the most important favourable structural changes that has taken place in the Spanish insurance industry is the change in attitude of insurance companies as regards how products are put together. Until not so long ago, at a point in time that can be placed around the date Law 33/1984 came into force, insurance companies designed their products according to their criteria and consulting, at the very most, their agents. These products were then launched onto the market and customers could take them or leave them. Furthermore, these products remained on the market for a long time.

The situation has now changed radically. Now customers design the products and companies are constantly trying to find out about the needs of prospective policyholders, by carrying out market research motivation analyses, statistics of how products are performing, etc.

This movement has also meant that products have fast become obsolescent, to such an extent that it has been estimated that in a typical general business insurance company, most of its portfolio consists of products that have been launched onto the market over the last five years.

This means that companies must provide their agents or sales staff with a wide range of competitive products, which are constantly being altered, which means that they must be constantly researching and training so that all the people affected can keep up to date. 
How fast a company is able to react to a new situation is probably one of the best possibilities for gaining competitive advantage.

Another weapon used in competition, which is where a large part of the advances in the insurance market are expected to be focused, refers to services. This term can be understood in two ways, both of which are important. Firstly, the incorporation of new services in addition to pure risk coverage and secondly, the quality of all the services being provided to policyholders.

Nowadays, there is no such thing as reinsurance cover that does not include a series of valuable services for the ceding company. Likewise, not just tomorrow's policyholders but even today's expect their insurer to provide them with a series of complementary services.

In life insurance, which has a saving component, or in retirement plans underwritten by insurance companies, for example, pure coverage must be accompanied by tax and financial advice, so that the policyholder can get a global response to his global needs: protection, profitability, tax advantages. This is just one example.

In property and casualty insurance, risk management, either from outside or supplied, preventive measures (qualification of installers, approved products, mechanisms, isolating materials, etc.) are just some of the services that are most commonly provided by insurance companies as a complement to insurance cover.

The quality of the services provided is a human problem (training, corporate culture, staff selection, etc.) and a management problem (control, express quality control targets, etc.).

\subsection{The advantages of information technology}

The profound changes that have taken place in insurance companies as a result of the progress made in computing and data communications, fundamentally, are no secret to anyone.

One consequence, which is perhaps not given its true value, is that there has been a huge gain in productivity in the Spanish insurance industry, which has led to lower costs per production unit. The large increase in the number of computer-related jobs in insurance entities, the fact that non-specialized jobs have virtually disappeared, are a clear sign of this profound structural change.

Moreover, the huge reduction in the cost and size of computer equipment, without any loss in computing power, has meant that small and medium-sized companies now have access to data pocessing possibilities that were once thought to be reserved for large companies.

The wealth of information and the speed with which it can be obtained has enabled entities to move on from statistical computing to management computing, which makes it possible to take decisions for making corrections or changes on a timely basis.

The linking of computers by telephone has enabled peripheral costs to be significantly reduced, and management possibilities, for instance, in other countries, with a small team, a reduction in jobs not related to sales for agents and brokers, etc., etc.

This means that a company must pay a great deal of attention to what technological advances are being made in this field (which does not mean that it always has to have "the very latest thing"), because some of these advances may offer competitive advantages. 


\subsection{Solidarity in the industry}

One aspect that often is not considered in microeconomic analysis, because of a lack of perspective, but which cannot be absent from a microeconomic analysis of the industry, concerns solidarity in the industry.

There is obviously a need for a Body to represent the business interests of the industry. There are some things that companies, taken separately, cannot, should not or do not want to do. These are precisely the things that should be done by organizations that represent the industry. This happens in countries all around the world.

This need is further strengthened by the growing presence of the public authorities in social and economic life. The Spanish philosopher Juan Marías wrote not long ago that never before have politicians spoken so much about freedom; but at the same time, never before have there been so many rules at all levels (European Community, State, Regional and Municipal) which restrict this very freedom.

Only an attitude agreed upon in the specialised busines organisation and between this body and the top business organisation, makes it possible to combat the new charges and interventions of public authorities under better conditions.

The advantage of such bodies is that they are granted by Law considerable powers of legal and political action, without being subject in any way to the authorities that control insurance. This gives them a great deal of independence, something that is impossible for a single Entity, which is always likely to be the object of administrative measures of reaction (inspection, difficulties about permits, etc.).

Moreover, the globalization of the economy means that the bodies that handle such matters must also be global in nature. For example, the Commission of the European Communities talks to a body with the appropriate scope, the European Insurance Committee, which is, in turn, made up of National Associations.

This is where there is a need, purely out of self-interest, to be able to have a say in the events that are being resolved outside the areas of individual companies, for immediate solidarity with other businesses in the industry and mediate solidarity with businesses in all other activities, which not only are an ethical measure that is to be recommended, but also a requirement for efficiency. One should not overlook the fact the insurance companies are, first and foremost, businesses, and only after that, insurance (labour rigidity, Social Security contributions, general tax treatment, etc.) and that as insurance businesses, their problems are similar to those of other businesses in the same industry (legal regulations, valuation of assets, specific tax treatment, control and penalties, etc.).

Lack of solidarity, far from any ethical qualification, simply is not consistent with the companies' own self-interest.

A company that shows solidarity is a company that is well-informed and has a greater say in the affairs of the world around it.

\subsection{On-going training and recycling}

Nobody doubts that companies that fail to adapt become fossilized and disappear. Here also one finds biological evolution.

What is happening is that never in the past have there been as many changes in as many aspects as now. And, what is more, cycles are becoming shorter, so that the new situation 
brought about by a change does not remain unaltered for very long. This is what has been called "the acceleration of history".

At the same time, business activity is becoming ever more complex and there are more and more elements, including those that apparently do not affect us, that combine together in the activity of an insurance company, as has been shown at the beginning of this work.

Faced with the challenge of more changes and less time between changes, the only response is on-going training and recycling.

Everyone agrees, for example, to train agents, who need to be provided with the information and arguments they need to keep policyholders satisfied when new situations arise, with new products, faced with other rival products that are more modern and better suited to customers' new needs.

It is not, however, as common to hear that the people who need to constantly recycle are the managers. The reason is clear and is based on the fact that their job is the most complex of all and that they concentrate the company's decision making powers (and the power to react).

The employees of insurance companies are becoming increasingly specialized, as computers have eliminated repetitive jobs. And, for instance, technical staffs do not always understand the problems of sales staffs or the employees in the claims department do not always realize that theirs is one of the most important sales functions in their company, perhaps the only time the company is in direct contact with its policyholder.

\subsection{The importance of channels of distribution}

Creating, maintaining and exploiting different channels of distribution is one of the keys to an insurance company's success in any market.

In principle, if one considers that insurance has not yet sufficiently penetrated Spanish society or its economy, it is clear that one cannot reject "a priori" any channel of distribution. Everything will depend on the relationship between economic and human resources needed and how profitable each channel is.

It has to be said that the Spanish Mediation Act has considerably liberalized this field, especially as regards tied agents and intermediation by banks.

We have already seen that insurance companies can gain advantages by using the distribution networks of banks, that give them access to the extremely wide range of bank customers, as well as the possibility of using their own network of agents to sell purely financial products that complement, as the case may be, insurance covers.

But having said this, I must immediately add that, as is shown by the experience of countries where banks and insurance companies have gone further in their collaboration, the typical channel of distribution preferred is still through insurance agents. What is happening is that pure sales people are being replaced by specialists, advisors of consultants in protection and connected services and, where necessary, in asset management, by the force of events and as a result of on-going training.

In Europe, banks have acted as their customers' financial advisers. In the United States, however, insurance companies have set up their own separate, albeit dependent, 
"asset management" companies to enable the insurance group to provide the global services demanded by its policyholders.

\subsection{The multinational dimension}

Earlier on we took a look at some of the advantages of operating in different countries.

The existence of the Single Market as a single territory without internal frontiers; the removal of discrimination against companies from EEC countries on account of their nationality; the multinational character of customers, especially industrial customers; the standardisation of legislations on guarantees and control over insurance companies; all of these are reasons that would appear to invite insurance companies to expand their area of operations to cover the entire EEC.

However, the reasons relating to competitive possibilities are undoubtedly the most powerful :

- Different tax systems which have not been harmonized, but instead compete against one another in the different member States of the European Union;

- The widely differing inflation rates in different countries ;

- The major differences in currency movements in member States, at the same time as considerable freedom in monetary coherence;

- Different premium rates and laws on insurance contracts. This is particularly important when such rates and laws can apply in different countries ;

- The wide variance in the attitudes of insurance control authorities, as a result of which the same EEC rules can be more or less favourable depending on how the control authority is located further to the North or to the South;

- Etc., etc.

These are all instruments of trading and management flexibility that only become available to companies that are multinational, providing them with a competitive advantage, which cannot be used by companies that operate only in the markets of their own countries, with the area of the Single Market.

Naturally, this will depend on the financial resources of the company and its strategic objectives, but this does not change the different competitive possibilities.

An especially promising area of expansion for Spanish insurance are the countries of Latin America. There are several reasons for this:

- The help some of these countries are receiving from UNESPA and from Spanish insurance to modify their legislative structures on insurance means that their requirements and guarantees show a certain degree of similarity with those of Spain and the EEC.

- Spain offers good technology and a high level of development which makes it an useful partner without being so powerful as to make these countries fear economic colonization which is how they feel, rightly or wrongly, about some other countries. Spanish insurers are welcomed. UNESPA's role has been that of a Chamber of Commerce. Spanish companies can contribute to modern services that would in all likelihood be appreciated by Latin American consumers.

- The roots of the general legal system of Latin American countries are the same as those of the Spanish system, which, itself based on Roman Law, Germanic Law and the Napoleonic 
Code, is very similar to the systems of many other EEC countries in central and southern Europe. The insurance rules designed by the EEC fit into the legal systems of Latin America in much the same way as they do in Europe.

- The difficulties of liberalization when faced with countries that are more powerful in the field of insurance, which have been overcome by Spain with some success, are a reassuring experience for the authorities in Latin American countries, who are not used to international competition.

- The fact that some countries in Latin America belong to wider regional agreements (NAFTA, Andean Pact, Mercosur, etc.) offers further appeal.

- Latin American countries, although their economic levels are much lower than in Europe, are recording growth rates that are $50 \%$ higher than in the EEC.

- All this without mentioning other additional factors: language, culture, mentality, easy integration, etc.

\subsection{Conclusion}

Insurance activity is very stimulating, and if one wishes, can be very challenging. Its variety and complexity, in spite of the fact that its basic principles are the same, as well as its rapid development in order to adapt to changes in its environment, have a number of effects. First of all, one never feels that insurance is under control. Secondly, it turns out that even what we did know becomes outdated after a few years. This is perhaps why working in insurance calls for humility. Furthermore, it is an activity which, like the priesthood or politics "marks one's character". An insurer never forgets insurance, even when he engages in a different profession. This is something that has been proven many times, in Spain at least.

Perhaps the underlying reason is that people become "hooked" on insurance, as if it were a soft drug. The fact is that it is an activity that is personally gratifying.

I have on one occasion affirmed, perhaps stretching the meanings of terms a little too far, that insurance is business-organized charity. What it has in common with charity is that it combines the (premiums) of a large number of units (persons, things) that are going to pay but who are not going to need the protection of insurance.

Who gets the money so collected? Precisely those who need it, because there has been an accident or a circumstance which creates an economic need. In this respect, insurance and charity bear comparison: in the effect of spreading the needs of a few among many people.

Insurance, however, is not contracted out of charity, but rather because each of the parties has an interest in doing so. This, in turn, has a positive psychological effect. Charity does not have to humiliate the people who receive it, but it is not uncommon for people who receive charity to feel humiliated. This is not the case with insurance, because the person receiving indemnity is exercising a right. It is simply the performance of a contract.

When one thinks about the billions of human problems that have been resolved by insurance throughout its history, one cannot but feel proud of our profession, even though this is not always recognized by society.

Some American authors have compared insurance to psychoanalysis or confession, as a method of eliminating the anxiety that is often generated by uncertainty. People who take 
out insurance eliminate the risk and thus remove uncertainty and anxiety. This reassuring effect does not happen alone, as in the case of indemnities for people who suffer an accident : it should happen to everyone who covers a risk with an insurance contract of any kind.

I do not know that much has been written about the subject of insurance and democracy. This is however an essential, unfailing relationship. In Eastern European countries, and unfortunately in many others, the case was and often still is that people can get security from the State, from the day they are born until their dying day. However, in exchange they must pay the high price of losing their freedom. Insurance also offers people security, but at the same time fully respects their personal and economic freedom. This is why it is not by chance that insurance, especially life insurance, has developed furthest in countries which have the greatest tradition of democracy.

It is perhaps in these aspects, that are so profoundly human, that one finds the highest quality of the services we provide people and society.

All of this, of course, without mentioning the economic effects, which include the following, among others :

a) Insurance facilitates investment and the creation of companies that would not have occurred, had insurance not existed;

b) It means that corporate savings can be brought down to the lowest level technically possible, represented by insurance premiums;

c) It captures short, medium and long-term savings, which are subsequently transformed by insurance into long-term investment. Many workers in all kinds of sectors of the economy do not know that their job has been created as a result of financing by an insurance company who has purchased shares or subscribed to bonds that have made it possible to set up the company and create the jobs ;

d) It systematically encourages the public-spirited idea that individuals and companies have a responsibility towards others; it allows a debtor to be solvent rather than suffering through the fault or negligence of others, etc.

When the famous democratic politician of the last century, Antonio Cánovas del Castillo, was asked by a journalist: "If you had not been Spanish, what would you have liked to be?", he swiftly replied: "Spanish".

If the author of this work, after fifty years in insurance, were asked: "If you had not been an insurer, what would you have liked to be?". He would have replied likewise: "An insurer". 